\title{
СУЧАСНІ ІНФОРМАЦІЙНІ ТЕХНОЛОГІЇ БЕЗПЕРЕРВНОГО ПРОФЕСІЙНОГО РОЗВИТКУ ЛІКАРІВ-РЕАБІЛІТОЛОГІВ
}

\author{
О. В. Сарканич
}

\author{
Національний університет охорони здоров'я України імені П. Л. Шупика
}

\begin{abstract}
Обговорено питання безперервного професійного розвитку реабілітологів, лікарів санаторно-курортного профілю. Проаналізовано можливості дистанційної освіти та особливості оцінювання компетентностей і знань лікарів у мобільній медицині. Дослідження спрямовано на обґрунтування стратегії навчальних програм реабілітологів і оцінювання можливості дистанційної перевірки знань. Запропоновано для завдань навчання лікарів санаторно-курортного спрямування користуватися логікою побудови ієрархії клінічних даних - онтологічних моделей. Створено реабілітаційно-орієнтовану онтологію, що надає необхідні пояснення та забезпечує можливості персоналізації, засновані на структурних зв'язках між клінічними поняттями в онтології. Віддалене надання медичної допомоги можливе за умови відповідної концептуалізації, що базується на принципах обґрунтування сталих станів, тригерно-каскадних уявленнях, використання онтологій знань. На післядипломному етапі освіти лікаря - спеціаліста дистанційне навчання повинно стати важливою частиною навчального процесу. Спілкування з пацієнтами, й особливо людьми з інвалідністю, накладає особливі вимоги на реабілітологів стосовно їхньої просресійної підготовки в питаннях дотримання правил етики та деонтології. Удосконалення знань морально-етичних і деонтологічних основ спілкування з пацієнтами та особливостей психологічного стану людей із інвалідністю сприятимуть безконфрліктній атмосфері процесів лікування та відновлення здоров'я пацієнтів. Загальне поширення інфрормації не гарантує ії якості та достовірності, хоча й сприяє формуванню більш свідомих і самостійних спеціалістів. Традиційна комунікаційна модель освіти поступилася місцем більш відкритим і партисипативним моделям, у рамках яких лікарі, діючи в широкому діапазоні навчальних середовищ і мереж, обмінюються інформацією та знаннями з іншими учасниками..
\end{abstract}

Ключові слова: інформаційні технології, безперервний професійний розвиток лікарів-реабілітологів, санаторнокурортна допомога, формальна, неформальна та інформальна освіта, зворотний зв'язок, оцінювання компетентностей.

\section{MODERN INFORMATION TECHNOLOGIES OF CONTINUOUS PROFESSIONAL DEVELOPMENT OF REHABILITATORS}

O. V. Sarkanych

\author{
Shupyk National Healthcare University of Ukraine
}

Background. Issues of continuous professional development of rehabilitation specialists, doctors of sanatorium profile are considered. Possibilities of distance education and features of assessment of competences and knowledge of doctors in mobile medicine are analyzed. The purpose of the study was to substantiate the strategy of rehabilitation programs for rehabilitation and assess the possibility of remote testing.

Materials and methods. Results. It is offered to use logic of construction of hierarchy of clinical data - ontological models for tasks of training of doctors of sanatorium-resort direction. A rehabilitation-oriented ontology is proposed that provides the necessary explanations and provides personalization capabilities based on the structural connections between clinical concepts in the ontology. Remote provision of medical care is possible under the condition of appropriate conceptualization, which is based on the principles of substantiation of steady states, trigger-cascade representations, use of ontologies of knowledge. At the postgraduate stage of education of a specialist, distance learning should become an important part of the educational process. Communication with patients, and especially people with disabilities, imposes special requirements on rehabilitation specialists for their professional training in compliance with the rules of ethics and deontology. Improving the knowledge of moral, ethical and deontological bases of communication with patients and the peculiarities of the psychological state of people with disabilities will contribute to a conflict-free atmosphere of treatment and recovery of patients.

Conclusions. The general dissemination of information does not guarantee its quality and reliability, although it contributes to the formation of more conscious and independent professionals. The traditional communication model of education has given way to more open and participatory models in which physicians, acting in a wide range of learning environments and networks, share information and knowledge with other participants.

Key words: information technologies, continuous professional development of doctors-rehabilitation specialists, sanatorium-and-spa care, formal, non-formal and informal education, feedback at the CPD, assessment of competencies. 


\title{
СОВРЕМЕННЫЕ ИНФОРМАЦИОННЫЕ ТЕХНОЛОГИИ НЕПРЕРЫВНОГО ПРОФЕССИОНАЛЬНОГО РАЗВИТИЯ ВРАЧЕЙ-РЕАБИЛИТОЛОГОВ
}

\author{
А. В. Сарканич \\ Национальный университет здравоохранения Украины имени П. Л. Шупика
}

\begin{abstract}
Обсуждены вопросы непрерывного профрессионального развития реабилитологов, врачей санаторно-курортного профиля. Проанализированы возможности дистанционного образования и особенности оценивания компетентностей и знаний врачей в мобильной медицине. Исследование направлено на обоснование стратегии учебных программ реабилитологов и оценки возможностей дистанционной проверки знаний. Предложено для задач обучения врачей санаторно-курортного направления пользоваться логикой построения иерархии клинических данных — онтологических моделей.

Разработана реабилитационно-ориентированная онтология, предоставляющая необходимые объяснения при обучении и обеспечивающая возможности персонализации образования. Удаленное оказание медицинской помощи возможно при условии соответствующей концептуализации, основанной на принципах обоснования устойчивых состояний, триггернокаскадных представлениях, использования онтологий знаний. На последипломном этапе образования врача - специалиста дистанционное обучение должно стать важной частью учебного процесса. Общение с пациентами, и особенно людьми с инвалидностью, накладывает особые требования на реабилитологов относительно их профрессиональной подготовки в вопросах соблюдения правил этики и деонтологии. Совершенствование знаний морально-этических и деонтологических основ общения с пациентами и особенностей психологического состояния людей с инвалидностью способствует бесконфрликтной атмоссрере процессов лечения и восстановления здоровья пациентов. Общее распространение информации не гарантирует ее качества и достоверности, хотя и способствует фрормированию более сознательных и самостоятельных специалистов. Традиционная коммуникационная модель образования уступила место более открытым и партисипативным моделям, в рамках которых врачи, действуя в широком диапазоне учебных сред и сетей, обмениваются информацией и знаниями с другими участниками.
\end{abstract}

Ключевые слова: иноормационные технологии, непрерывное профессиональное развитие врачей-реабилитологов, санаторно-курортная помощь, фрормальное, неформальное и информальное образование, обратная связь при НПР, оценка компетентностей.

Вступ. Безперервний професійний розвиток (БПР) є важливим аспектом у професії фізіотерапевта для підтримки знань та розуміння теорії і практики фізіотерапії. Медичні працівники повинні брати участь у безперервному професійному розвитку за різноманітним спектром, щоб регулярно покращувати свої професійні знання та навики для підвищення професійної чесності та лідерства в цьому конкурентному світі [8].

Для реабілітологів мають бути використані різні форми БПР. Існує необхідність у більшому розумінні неформальних та інформальних форм БПР, що доповнюють формальне навчання. У багаточисельних попередніх дослідженнях було підтверджено, що БПР заснований на сильних наукових доказах і різноманітних технічних та управлінських навиках. Він може покращити реабілітаційну практику $[4,13,14]$.

Хоча БПР можна розглядати як процес, що стосується інтересів спеціалістів і планів стосовно свого особистого розвитку, проте, він не може гарантувати формування компетентностей [9]. Це призводить до іншого фундаментального питання про те, чи забезпечується безпека пацієнта при такому навчанні, чи гарантується доступ до новітніх технологій надання медичної (реабілітаційної) допомоги.
Концепція науково обгрунтованої практики заохочує медичних працівників надавати найбільш ефективну медичну допомогу та нести відповідальність за проведені ними заходи. Відомо, що фізіотерапевти навчаються інакше в порівнянні з іншими суміжними медичними працівниками. Тому вважали, що дослідницькі навчальні програми - це заходи щодо трансферу знань (Т3), спрямовані на поліпшення засвоєння реабілітологами наукових даних. Хоча повідомлялося, що програми навчання за допомогою ТЗ значно покращують сприйняття фактичних даних фізіотерапевтами, досі не ясно, які аспекти навчання оптимально допомагають Т3 у фізіотерапевтичної практиці [75].

Мета роботи: обгрунтування стратегії навчальних програм реабілітологів із можливістю оцінювання дистанційної перевірки знань.

Матеріал і методи дослідження. Для реалізації мети дослідження проведено два види опитування слухачів, які навчалися в Навчальному центрі Національного університету охорони здоров'я України імені П. Л. Шупика (раніше НМАПО імені П. Л. Шупика) в санаторії «Квітка полонини» ТОВ «Сузір'я» протягом 2018-2020 років. У першому опитуванні з питань зворотного зв'язку взяли участь 75 слухачів, у другому — 3 питань 
оцінювання знань 65 слухачів. Дизайн дослідження - суцільна вибірка.

Результати та їх обговорення. Завдяки інтеграції між здатністю лікарів приймати клінічні рішення за наявними дослідними даними, вибором і переконаннями пацієнтів у санаторії «Квітка полонини» успішно засвоюються принципи доказової практики. Навчальні програми ТЗ розроблено на моделях зміни поведінки та теоріях навчання. Програма, що не має фундаментальної теоретичної основи, може бути менш якісною а, отже, менш ефективною. Викладачам же важливо розуміти не тільки найбільш релевантну теорію зміни поведінки для різних суміжних медичних дисциплін, що вони викладають, але й проводити навчання найбільш прийнятним для своєї аудиторії чином.

Особливості навчальних програм БПР реабілітологів. Використання принципів доказової медицини в навчанні. Особливість розроблених нами навчальних програм БПР реабілітологів полягає в наголошенні на важливості представлення інформації різними способами. Це означає, що слухачі циклів тематичного вдосконалення, знаходячись у рамках навчальної програми, могли активно виявляти та обговорювати питання, які можуть стримувати їх при впровадженні фактичних даних на практиці. Обмін цією інформацією з колегами під час навчання та проведення дискусій за сприяння викладача могли б допомогти у визначенні рішень проблем локального контексту, а не бути для лікарів виключно вправою.

Дані зворотного зв'язку зі слухачами свідчать, що принаймні через три місяці після навчання відзначалось значне покращення логіки прийняття рішень у практичних ситуаціях. Вважаємо, що це обумовлено застосуванням багатоаспектної навчальної програми. У той же час не виявлено оптимальної послідовності елементів навчальних програм. Крім того, не виявлено суттєвого підвищення віддалених результатів при суттєвому розширенні кількості навчальних модулів. Багатоаспектні програми, які включають щонайменше п'ять різних елементів (окрім базових) більш ефективні для досягнення значних результатів навчання, ніж програми з меншою кількістю елементів.

Особливості зворотного зв'язку при БПР реабілітологів. Нами проаналізовано результати зворотного зв'язку, запропонованого у дослідженні лікарям-курортологам [16, 17] за модифікованою до завдань нашої роботи анкетою (табл. 1). Проведено опитування лікарів, які пройшли підвищення кваліфікації в очно-заочному форматі 3 елементами дистанційної освіти. Подібний аналіз нами трактується як перший крок аналізу ефективності підготовки лікарів-реабілітологів. Зрозуміло, що в дійсності формування компетенцій можливо перевірити лише під час професійної роботи спеціаліста.

Таблиця 1

Показники зворотного зв'язку якості навчання лікарів-реабілітологів

\begin{tabular}{|c|c|c|c|c|c|c|c|c|c|}
\hline \multirow{2}{*}{$\begin{array}{l}\text { № } \\
\text { 3/ח }\end{array}$} & \multirow{2}{*}{ Мета навчального курсу } & \multicolumn{2}{|c|}{$\begin{array}{l}\text { Повністю } \\
\text { погоджуюсь }\end{array}$} & \multicolumn{2}{|c|}{$\begin{array}{l}\text { Більшою мірою } \\
\text { погоджуюсь }\end{array}$} & \multicolumn{2}{|c|}{$\begin{array}{c}\text { Частково } \\
\text { погоджуюсь }\end{array}$} & \multicolumn{2}{|c|}{$\begin{array}{c}\text { Не } \\
\text { погоджуюсь }\end{array}$} \\
\hline & & абс. & $\%$ & абс. & $\%$ & абс. & $\%$ & абс. & $\%$ \\
\hline 1 & $\begin{array}{l}\text { Надано повну інформацію про мету } \\
\text { навчального курсу до його початку }\end{array}$ & 7 & 35,0 & 5 & 25,0 & 4 & 20,0 & 4 & 20,0 \\
\hline 2 & $\begin{array}{l}\text { Навчальний курс сприяв успішному } \\
\text { обміну інформацією та засвоєнню } \\
\text { нових технологій }\end{array}$ & 10 & 50,0 & 10 & 50,0 & 0 & 0 & 0 & 0 \\
\hline 3 & $\begin{array}{l}\text { Курс охоплював теми, що мені по- } \\
\text { трібно було вивчити }\end{array}$ & 16 & 80,0 & 4 & 20,0 & 0 & 0 & 0 & 0 \\
\hline 4 & $\begin{array}{l}\text { Мета курсу була досягнута відпо- } \\
\text { відно до плану навчального курсу }\end{array}$ & 18 & 90,0 & 10 & 50,0 & 0 & 0 & 0 & 0 \\
\hline
\end{tabular}


Продовж. табл. 1

\begin{tabular}{|c|c|c|c|c|c|c|c|c|c|}
\hline \multirow{2}{*}{$\begin{array}{l}\text { № } \\
\text { 3/ח }\end{array}$} & \multirow{2}{*}{ Мета навчального курсу } & \multicolumn{2}{|c|}{$\begin{array}{c}\text { Повністю } \\
\text { погоджуюсь }\end{array}$} & \multicolumn{2}{|c|}{$\begin{array}{c}\text { Більшою мірою } \\
\text { погоджуюсь }\end{array}$} & \multicolumn{2}{|c|}{$\begin{array}{c}\text { Частково } \\
\text { погоджуюсь }\end{array}$} & \multicolumn{2}{|c|}{$\begin{array}{c}\text { Не } \\
\text { погоджуюсь }\end{array}$} \\
\hline & & абс. & $\%$ & абс. & $\%$ & абс. & $\%$ & абс. & $\%$ \\
\hline 5 & $\begin{array}{l}\text { Програма складена з урахуванням } \\
\text { побажань слухачів }\end{array}$ & 6 & 30,0 & 12 & 60,0 & 2 & 10,0 & 0 & 0 \\
\hline 6 & $\begin{array}{l}\text { Методи передавання знань обрано } \\
\text { відповідно: }\end{array}$ & & & & & & & & \\
\hline 6.1 & Змістовні узагальнюючі лекції & 15 & 75,0 & 5 & 25,0 & 0 & 0 & 0 & 0 \\
\hline 6.2 & $\begin{array}{l}\text { Ефективні загальні обговорення } \\
\text { з використанням різних методів } \\
\text { навчання, зокрема "мозковий штурм" }\end{array}$ & 11 & 55,0 & 9 & 45,0 & 0 & 0 & 0 & 0 \\
\hline 6.3 & $\begin{array}{l}\text { Ефективні загальні обговорення } \\
\text { з використанням різних методів } \\
\text { навчання, зокрема "рольова гра" }\end{array}$ & 10 & 50,0 & 6 & 30,0 & 3 & 15,0 & 1 & 5,0 \\
\hline 6.4 & $\begin{array}{l}\text { Змістовні обговорення } \\
\text { завдань у малих групах }\end{array}$ & 10 & 50,0 & 10 & 50,0 & 0 & 0 & 0 & 0 \\
\hline 6.5 & Симуляційне навчання & 10 & 50,0 & 6 & 30,0 & 4 & 20,0 & 0 & 0 \\
\hline 7 & Мова під час лекцій зрозуміла & 17 & 85,0 & 3 & 15,0 & 0 & 0 & 0 & 0 \\
\hline 8 & $\begin{array}{l}\text { Загальна атмосфера під час курсу } \\
\text { сприяла навчальному процесу }\end{array}$ & 14 & 70,0 & 6 & 30,0 & 0 & 0 & 0 & 0 \\
\hline 9 & $\begin{array}{l}\text { Навчання сприяло розвитку } \\
\text { командної роботи та співробітництва } \\
\text { між участниками }\end{array}$ & 10 & 50,0 & 10 & 50,0 & 0 & 0 & 0 & 0 \\
\hline 10 & Викладачі мають гарні знання & 18 & 90,0 & 2 & 10,0 & 0 & 0 & 0 & 0 \\
\hline 11 & Викладачі добре спілкуються & 16 & 80,0 & 4 & 20,0 & 0 & 0 & 0 & 0 \\
\hline 12 & $\begin{array}{l}\text { Викладачі відкриті та справедливі } \\
\text { по відношенню до всіх }\end{array}$ & 16 & 80,0 & 4 & 20,0 & 0 & 0 & 0 & 0 \\
\hline 13 & Загальні характеристики структури: & & & & & & & & \\
\hline 13.1 & $\begin{array}{l}\text { Модуль 1: Введення в курс } \\
\text { визначення наступності }\end{array}$ & 17 & 85,0 & 3 & 15,0 & 0 & 0 & 0 & 0 \\
\hline 13.2 & Модуль 2: Формування мотивації & 15 & 75,0 & 5 & 25,0 & 0 & 0 & 0 & 0 \\
\hline 13.3 & Модуль 3: Створення команди & 14 & 70,0 & 6 & 30,0 & 0 & 0 & 0 & 0 \\
\hline 13.4 & $\begin{array}{l}\text { Модуль 4: Тайм-менеджмент } \\
\text { та самоуправління }\end{array}$ & 12 & 60,0 & 8 & 40,0 & 0 & 0 & 0 & 0 \\
\hline
\end{tabular}


Продовж. табл. 1

\begin{tabular}{|c|c|c|c|c|c|c|c|c|c|}
\hline \multirow{2}{*}{$\begin{array}{l}\text { № } \\
\text { 3/п }\end{array}$} & \multirow{2}{*}{ Мета навчального курсу } & \multicolumn{2}{|c|}{$\begin{array}{c}\text { Повністю } \\
\text { погоджуюсь }\end{array}$} & \multicolumn{2}{|c|}{$\begin{array}{c}\text { Більшою мірою } \\
\text { погоджуюсь }\end{array}$} & \multicolumn{2}{|c|}{$\begin{array}{c}\text { Частково } \\
\text { погоджуюсь }\end{array}$} & \multicolumn{2}{|c|}{$\begin{array}{c}\text { Не } \\
\text { погоджуюсь }\end{array}$} \\
\hline & & абс. & $\%$ & абс. & $\%$ & абс. & $\%$ & абс. & $\%$ \\
\hline & $\begin{array}{l}\text { Інформаційні технології } \\
\text { в реабілітології }\end{array}$ & & & & & & & & \\
\hline 13.5 & $\begin{array}{l}\text { Модуль 5: Управлінські } \\
\text { навики для лідерів }\end{array}$ & 12 & 60,0 & 8 & 40,0 & 0 & 0 & 0 & 0 \\
\hline 13.6 & Модуль 6: Досконала практика & 16 & 80,0 & 4 & 20,0 & 0 & 0 & 0 & 0 \\
\hline & Загальні характеристики курсу & & & & & & & & \\
\hline 14 & $\begin{array}{l}\text { Кожному модулю присвячено } \\
\text { достатньо часу }\end{array}$ & 11 & 55,0 & 9 & 45,0 & 0 & 0 & 0 & 0 \\
\hline 15 & $\begin{array}{l}\text { Надано достатньо часу } \\
\text { для зворотного зв’язку }\end{array}$ & 9 & 45,0 & 11 & 55,0 & 0 & 0 & 0 & 0 \\
\hline
\end{tabular}

Як бачимо з табл. 1 переважна більшість слухачів сприймає БПР як ефективну систему трансферу знань. Адже, з тим, що мета курсу повністю досягається погодилися $80 \pm 4,9$ \% слухачів. Мова спілкування була зрозумілою $85 \pm 4,5 \%$ слухачів, організована досконала практика $87 \pm 4,2 \%$ тощо. Такі статистичні дані дають можливість стверджувати, що подібна форма передавання знань практично повністю задовольняє лікарів під час БПР.

У той же час окремі форми трансферу знань, що пов'язані $з$ неформальною освітою потребують обговорення. В першу чергу мова йде про дистанційну медицину.

Інформаційні оцінки дистанційної медици-

ни. Розвиток дистанційного моніторингу стану здоров'я (а при необхідності невідкладної допомоги) пацієнтів обумовив появу нової галузі досліджень, що отримала назву віддаленої охорони здоров'я. Перевагами дистанційного моніторингу пацієнтів $€$ : раннє та оперативне виявлення захворювань, можливість постійного спостереження за пацієнтами, профілактика загострення захворювань, зниження витрат на госпіталізацію, отримання більш точних показань при одночасному забезпеченні повсякденної активності пацієнтів, підвищення ефективності медичних послуг за рахунок використання комунікаційних технологій $[1,11]$.
Напрям мобільної охорони здоров'я має багато категорій. Практично всі вони базуються на визначенні стану пацієнтів за допомогою інформаційних технологій поза стаціонарних умов [6]. Реалізація дистанційного моніторингу стану пацієнтів може бути пов'язана з консультаціями реаніматолога, перш за все тому, що він націлений на кілька підгруп пацієнтів із хронічними захворюваннями, пацієнтів із проблемами мобільності або іншою інвалідністю, післяопераційними станами, допомогою літнім пацієнтам. Відповідно, при використанні систем віддаленого моніторингу пацієнтів існує декілька проблем. Основні з них пов'язані з забезпеченням персоналізації медичної допомоги, обгрунтуванням системності та своєчасності діагностичних і лікувальних дій. Існують і технологічні проблеми, зокрема, вибір системи датчиків (контактних або безконтактних); обгрунтування алгоритмів оброблення даних; формування логіки оцінювання релевантності показників [2, 10].

Виникає завдання обгрунтування системних рішень щодо трансферу знань у технологіях використання дистанційного управління реабілітацією пацієнтів. При цьому важливо зауважити, що ефективність віддаленої медицини практично повністю залежить від коректного застосування системної медицини. Постійно зростаючі темпи проведення клінічних досліджень призводять до утворення величезних обсягів високопродуктивних даних [3, 5]. 
Управління масивами такої інформації вимагає не тільки й не стільки агрегації та інтеграції даних, скільки засобів їх оброблення (структуризації або класифікації) з метою подальшого використання в аналізі, вилученні та генерації знань.

Основи оцінювання компетентностей і знань при мобільному навчанні. Концептуалізація та загальні зауваження. Кожна процедура оцінювання компетентностей і знань розпочинається 3 проєктування мети, тобто з обгрунтування того, що повинно бути оцінено. Класифікація освітніх цілей, зазвичай, поділяє їх на три області: знання, навики та компетентності.

Цілі в галузі знань стосуються когнітивних заходів. Вони варіюють в континуумі від можливості згадати фактичні події до інтегруючих процесів для вирішення проблем. Цілі навиків включають психомоторні аспекти, що необхідні для ефективного лікаря-клініциста. Вони пов'язані з особистісними якостями суб'єкту навчання, його підходом до медицини та пацієнтів. Більш складним форматом $€$ цілі виміру компетентностей.

При оцінюванні фундаментальною властивістю будь-якого методу тестування $є$ те, що «він вимірює те, що він має намір виміряти». Це, по суті, й є валідність (міра довіри) та обгрунтованість оцінки. Тест може мати кілька аспектів валідності, що можуть бути скомпільовані для встановлення загальної валідності. 3 метою раціоналізації їі численних аспектів у навчальній літературі представлено ряд стандартів для оцінювання обгрунтованості того чи іншого інструменту [14]. Ці стандарти включають в себе ідентифікацію особи, оцінювання змісту, конструкції та міри довіри до процедури тестування (критеріальну валідність). Розглянемо їх послідовно.

Ідентифікація особи. Ця форма валідності найчастіше створює труднощі. Однак останні дослідження суттєво спрощують процедурні питання навіть при дистанційному навчанні.

Визначення форми комп’ютерного тестування. Передбачає автоматизовану генерацію варіантів тесту, здійснювану за допомогою інструментальних засобів. Варіанти створюються перед іспитом або безпосередньо під час його проведення з банку тестових завдань із стійкими статистичними характеристиками. Змістовна валідність і паралельність варіантів забезпечуються за рахунок суворо регламентованого відбору завдань кожного варіанту відповідно до специфікації тесту.

Останнім часом знаходить все більше розповсюдження комп'ютерне адаптивне тестування, що базується на спеціальних адаптивних тестах. В основі ідеї адаптивності лежать міркування про те, що суб’єкту навчання (інтерну, лікарю під час безперервного професійного розвитку) марно давати завдання тестів, що він виконає напевно правильно без найменших труднощів або гарантовано не впорається з ними в силу високої складності. Тому здійснювали індивідуальну (контингентну) підготовку завдань, що адаптовані до рівня підготовленості кожного суб'єкту навчання.

Зазвичай, психологічні та емоційні реакції лікарів, інтернів і студентів на комп’ютерне тестування носять позитивний характер. У принципі, їм подобається негайна видача тестових балів, протоколу тестування з результатом за кожним завданням, а також сам інноваційний характер контролю, особливо, коли залучаються сучасні гіпермедійні чи ігрові технології для видачі тесту, динамічний мультимедійний супровід завдань на комп’ютері. Загальною думкою слід вважати, що комп’ютерне тестування, забезпечує більш точне оцінювання знань і вмінь, сильніше мотивує до виконання завдань порівняно з класичними технологіями оцінювання знань. А якщо тестування проходить в адаптивному режимі, то скорочується час проведення іспиту та довжина тесту.

Слід ураховувати й певну кількість недоліків мобільного навчання. Так, відзначаються деякі негативні реакції учасників навчання, зокрема певні обмеження, що іноді накладаються при видачі завдань при комп'ютерному тестуванні. Наприклад, фіксується максимально можливий час виконання кожного завдання, після закінчення, якого незалежно від бажання випробуваного з'являється наступне завдання тесту. В адаптивному тестуванні слухачі та слухачі часто незадоволені тим, що вони не мають можливості пропустити чергове завдання, переглянути весь тест до початку роботи над ним і змінити відповіді на попередні завдання. Іноді слухачі заперечують проти комп’ютерного тестування через труднощі, що виникають при виконанні та записі математичних обчислень тощо.

Результати багатьох досліджень свідчать, що попередній досвід роботи на комп’ютері у багатьох 
випадках впливає на валідність результатів виконання тесту. Якщо в тест включено лінійні завдання 3 вибором відповідей, то вплив досвіду роботи 3 комп’ютером на результати тестування незначний, оскільки від тих, хто тестується в таких завданнях не потрібно ніяких складних дій при виконанні тесту. При розгалужених тестових завданнях або при застосуванні інноваційних типів завдань, що широко використовують засоби комп’ютерної графіки та інші нововведення, вплив попереднього комп’ютерного досвіду на тестовий бал стає дуже значним. Отже, при комп’ютерному тестуванні необхідно враховувати рівень комп’ютерного досвіду слухачів (лікарів, інтернів, студентів), для яких призначається тест.

Економічна ефективність. Вартість класичної (паперової) форми тестування, особливо в практичних умовах там, де може бути велика кількість людей, розташованих у різних місцях, може бути досить великою. Відповідно переваги переходу на мобільні системи включають усунення необхідності транспортування людей до установи, скорочення часу, необхідного для збору даних тестування, суттєве скорочення паперових форм та часу обробки даних за рахунок цифровізації тощо.

Для зменшення впливу досвіду роботи з комп’ютером на результати тестування включали в оболонки програм для комп’ютерної перевірки знань спеціальні інструкції і тренувальні вправи для кожної інноваційної форми завдань. Попередньо знайомили слухачів із інтерфейсом, проводили репетиційне тестування. Крім того проводили кластеризацію слухачів відповідно до наявного досвіду роботи з комп’ютером.

Отже, підсумовуючи сказане констатуємо, що комп’ютерне тестування дозволяє забезпечити об’єктивне та безперервне діагностування компетентностей, знань і вмінь суб’єктів навчання, в тому числі за допомогою мобільних пристроїв, здійснювати своєчасне коректування та усунення дефектів навчання, але потребує проведення обов’язкових і спеціальних процедур.

Кількісні характеристики якості навчання та оцінювання компетентностей, знань і навиків. Поняття валідності оцінок. Використання кількісних характеристик в оцінюванні знань і компетентностей вважається досить складним завданням. У наших дослідженнях використовували один із найбільш важливих показників — характеристику валідності.

Під валідністю, взагалі, розуміли рівень відсутності в інформації теоретичних помилок, пов'язаних або з невірністю вхідних теоретичних посилок при розробленні певної методики, або з невідповідністю числової моделі досліджуваної емпіричної системи. Підкреслимо, що в математичній статистиці під валідністю розуміється міра близькості отриманого значення (показника, характеристики, критерію) до середнього значення даного показника (критерію, характеристики) для даного класу явищ (подій). У доказовій медицині: валідність - комплексна характеристика методики (тесту), що включає відомості про область досліджуваних явищ і репрезентативність діагностичної процедури по відношенню до них. Найбільш просте та загальне формулювання - це «поняття, яке вказує нам, що тест вимірює та наскільки добре він це робить».

Власне кажучи, саме цей змістовний нюанс визначення валідності застосовували в наших дослідженнях. Серед досить великої кількості різновидів валідності (інкрементна, поточна, очевидна, прогностична, змістовна, емпірична, контентна, конструктивна тощо) найчастіше використовували критеріальну складову. Важливо зауважити, що єдиної стандартизованої процедури оцінювання валідності поки не існує. Конкретний математичний підхід обумовлюється особливостями поставленого завдання.

Надійність оцінювання якості навчання. Наступним важливим показником якості навчання слугувало оцінювання надійності. Кластер показників надійності охоплює цілу групу, що характеризують точність, стабільність, відтворюваність результатів інструментів оцінювання. Вони вимірюють ступінь, в якій випробування дасть один i той самий результат після декількох ітерацій при одних і тих самих умовах.

В основних математичних термінах надійність оцінюється як:

$$
\mathrm{R}_{\mathrm{x}}=\mathrm{V}_{\mathrm{t}} / \mathrm{V}_{\mathrm{x}},
$$

де $\mathrm{R}_{\mathrm{x}}$ - надійність спостережуваного (тестового) балу X; $\mathrm{V}_{\mathrm{t}}$ i V $\mathrm{V}_{\mathrm{x}}$ - мінливість «справжніх» (істинних характеристик, у даному випадку, знань і виміряних тестових балів відповідно).

Надійність реєструється як коефіцієнт за шкалою від 0 до 1. Зрозуміло, що тестове випробування 
3 коефіцієнтом надійності 0 зовсім ненадійно, 1 - можна довіряти. В цілому, надійність оцінювання легше визначити, ніж валідність. Як і для валідності, існує ряд методів для встановлення надійності тесту. Такі методи включають внутрішню узгодженість, тест-ретест, еквівалентні форми та взаємну надійність.

Надійність внутрішньої послідовності. Внутрішня узгодженість - це оцінка надійності, при якій один тест уводиться в одну групу один раз для визначення внутрішньої узгодженості тесту. Хоча існує багато типів внутрішньої узгодженості, спліт-половинна надійність прекрасно ілюструє цю концепцію. В зазначеному методі елементи, призначені для вимірювання однієї і тієї ж конструкції, випадковим чином поділяються на два набори. Проводиться весь тест і загальний бал розраховується для кожної випадкової половини. Оцінювання надійності поділу навпіл є кореляцією між цими двома балами. У більш складному, але схожому методі внутрішня узгодженість тесту вимірюється за допомогою коефіцієнта А. Кронбаха. По суті даний метод співвідносить успішність суб'єктів навчання з використанням усіх можливих випадкових розщеплень навпіл.

Надійність повторного випробування. Метод тест-ретест вимірює ступінь узгодженості результатів тесту з плином часу. Цей коефіцієнт надійності розраховується шляхом порівняння результатів одного і того ж тесту, введеного в одну і ту ж тестову сукупність у двох окремих випадках. Існує кілька проблем, пов’язаних із цим методом. По-перше, часто недоцільно проводити одне і те ж оцінювання в декількох випадках. По-друге, якщо тести проводяться дуже часто, то суб'єкти навчання запам'ятовують свої відповіді з самого початку заняття (тим самим штучно підвищуючи надійність перездавання тесту).

Взаємна надійність. У багатьох ситуаціях нами поширювався інструмент тестування для використання декількома екзаменаторами в різних випадках. У таких ситуаціях визначали взаємну надійність оцінювання, а саме ступінь, в якій результати тестування залежать від продуктивності кандидата, а не від конкретного екзаменатора. Наприклад, для оцінювання узгодженості двох осіб, які розглядають предмет із використанням категоріальних елементів, можна розрахувати процентну згоду.
В процедурах комп’ютерного тестування при мобільній освіті використовуються ще декілька важливих критеріїв. У першу чергу, це інформативність, що виражає значення інформації у вирішенні конкретних завдань; релевантність - міра відповідності інформації, що запитується та отримується та, нарешті, пертинентність — міра відповідності отримуваної інформації та потреби в ній.

Логіка оцінювання знань і компетентностей реабілітологів. На сьогоднішній день у всіх областях медичної освіти описано та використовується цілий ряд методів оцінювання знань і компетентностей. Кожен метод має свої власні властиві йому переваги та недоліки. При виборі методу важливо, щоб методика оцінювання була тісно пов'язана цільовою функцією тестування.

Під час оцінювання знань лікарів санаторнокурортного напряму слід брати до уваги характер їхньої діяльності. Одне з головних завдань санаторно-курортного лікування полягає в продовженні життя людини за рахунок інволютивного періоду (періоду старіння). Компетентність реабілітолога має враховувати, що основний шлях допомоги полягає в супроводі людини в перебігу життя, коректуючи його стиль і мінімізуючи фактори ризику. Відповідно, головна умова санаторного етапу ведення пацієнта — максимально можливий облік факторів ризику та індивідуальних особливостей людини. Здавалось би у санаторному процесі уточнення діагностики та лікування пацієнта, етапи їх індивідуалізації мінімальні. На практиці це не так.

Останніми роками в фізіотерапевтичній практиці стали застосовуватися фізичні фактори низької інтенсивності, так звані інформаційні впливи, що за даними експериментальних і клінічних досліджень впливають не тільки на енергетику, але й на хронобіологичні процеси структур і систем біооб'єкту, оптимізуючи його фізіологічні процеси. В цьому плані цікаво застосування структурно-резонансної терапії (СРТ), заснованої на використанні електромагнітного випромінювання та електричного струму в певному частотному ритмі функціонування живої матерії, що сприяє оптимізації діяльності біооб'єкту на субклітинному, клітинному, тканинному, органному, системному рівнях. Зазначене має враховуватись у системах комп'ютерного контролю знань і компетентностей.

Другою відміною в процедурах оцінювання знань $є$ виражений принцип індивідуалізації. 
Взагалі він добре відомий - $є$ однакові хвороби, але немає однакових пацієнтів. Практично в усіх посібниках із санаторно-курортного лікування, реабілітації пацієнтів обов'язково вказується, що головною особливістю реабілітаційного етапу лікування останніх є індивідуалізація. Проте, ніякого конкретного сенсу, найчастіше, не вкладається. Сьогодні важко відійти від стандартизованих підходів, але відносно людини можливо визначити найбільш підходящу для неї стратегію оздоровлення (вже підкреслювалось, що тільки для вибору режиму використання мінеральної води існують більше 10000 варіантів) або ефективний лікарський засіб (Л3) на основі індивідуальної фармакокінетики. Вона має здійснюватися з урахуванням особливостей організму, перебігу хвороби, попередньої терапії, щоб доцільно поєднувати бальнеотерапію, фізіотерапію, ЛФК, масаж, ортопедичне та інші види спеціального лікування, уникнути поліпрагмазії, енергетичного перевантаження організму.

Третя особливість полягає в урахуванні при оцінюванні знань реабілітологів необхідності аналізу динаміки показників, зокрема, технології з використанням моніторингу показників, що відповідають принципу персоналізації проведених процедур і оцінювати її ефективність. Сучасні тенденції розвитку відновлювальної медицини засновані на персоналізації програм застосування нефармацевтичних технологій у процесі медичної реабілітації та профілактики загострень хронічних захворювань.

В якості прикладу, наведемо моніторинг поверхневого імпедансу шкіри, покладений в основу загальної технології динамічної електронейростимуляції. Принцип динамічного лікування фізичними факторами, що полягає в змінюванні їхніх параметрів і зон впливу відповідно до змін актуального стану пацієнта, $€$ необхідною умовою ефективності фізіотерапії і становить основу ії персоналізованого застосування. В більшості відомих у даний час апаратів для через шкірної електронейростимуляції використовуються ручні регулювання параметрів і вибору зон стимуляції, регламентовані відповідними методичними рекомендаціями. При цьому в зв’язку з великою різноманітністю швидкозмінних індивідуальних реакцій на проведену процедуру реальної її персоналізації досягти проблематично. Відповідно автором показано, що актуальним стає застосування апаратури, яке забезпечує автоматичне змінення параметрів стимулюючих імпульсів на основі аналізу сигналів у відповідь на індивідуальні реакції. Такий підхід може служити для виявлення латентних тригерних точок, різні патерни розподілу яких, вимагають персоналізованого лікування.

Для оцінювання знань і компетентностей реабілітологів було обрано один із найбільш популярних способів ранжування клінічної компетентності піраміда Міллера. Зважаючи на основи тверджень піраміди Міллера оцінювання проводиться для лікарів, які навчаються в реальній клінічній обстановці. Це обгрунтування покладено й в основу концепції оцінювання на робочому місці, різних інструментів і способів, що розроблено навколо цього в останні десятиліття. Головне - за допомогою даної моделі робиться спроба поетапного формування клінічної компетентності. Когнітивна та поведінкова прогресія, що суб'єкт навчання здійснює від отримання знань до виконання завдання, ілюструється чотирма етапами: знає, вміє, показує як і робить. Тобто, якщо метою є перевірка фактичного засвоєння теорії («знає»), досить тесту з множинним вибором; якщо метою тестування $€$ розумовий процес кандидата («знає як»), формат іспиту може бути корисний при доповнені тесту, наприклад, розгалуженими алгоритмами.

У клінічній медицині важливо розрізняти те, що кандидат знає, і те, що він може зробити («показує як»). Тут важливі клінічні та практичні методи оцінювання. Важливість цих методів призвела до більш об'єктивним підходам до клінічного оцінювання. Добре відомі такі приклади, як об’єктивний структурований клінічний іспит (OSCE), об'єктивний структурований практичний аналіз (OSPE), об'єктивна структурована екзаменаційна відомість (OSLER), груповий об'єктивний структурований клінічний іспит (GOSCE) та інші.

Для визначення компетентності трикутник Міллера передбачатиме фактичні клінічні показники («робить»). Хоча багато інших чинників можуть впливати на клінічні показники.

Для вирішення цієї проблеми, запропоновано інші моделі, наприклад, «Кембриджська модель», яка розширює трикутник Міллера таким чином, щоб проілюструвати індивідуальні та системні впливи, пов’язані з продуктивністю. За допомогою 
моделі розрізняється компетентність (яку кандидат демонструє на іспиті) та результативність (те, що кандидат демонструє в реальній практиці); обумовлюється необхідність (коли це доцільно) доповнення отриманих справжніх клінічних показників оцінками знань і практичних навиків.

Важливим є оцінювання спілкування з пацієнтами, особливо в наш час, коли пацієнти описують не власні ознаки, а такі, що оброблені з урахуванням інформації в Інтернеті. Зазначена проблема виникає в зв'язку з тим, що пацієнти використовують мережу Інтернет не тільки для кращої обізнаності стосовно свого здоров'я, а, перш за все як найкращий засіб використання обмеженого часу на консультацію лікаря та «примусу» його більш серйозно віднести до їх проблем. Пацієнти очікують від лікарів прийняття такої інформації, її обговорення, викладення в належному контексті та висловлення своєї професійної думки. «Очищення» даних, безпосередньо отриманих від пацієнта, від наносної інформації й є віддзеркаленням уміння суб'єкта навчання спілкуватися з пацієнтом.

Реферування норм і критеріїв — це два поширені методи співвіднесення вихідних показників роботи суб'єктів навчання зі стандартом, що дозволяє проводити порівняння або ранжування.

Реферування норм $є$ більш традиційним методом і використовується для опису діяльності кандидата 3 точки зору його положення в групі. Результати, як правило, представляються у вигляді відсотка правильних відповідей, де кількість суб’єктів навчання для проходження або отримання конкретної оцінки визначена наперед. Динамічне оцінювання кількості відповідей називається «кривою оцінок» для даного класу явищ. I навпаки, критерій референтності має особливе значення в професійній освіті, де $є$ стурбованість стосовно досягнення мінімального рівня компетентності, а не зосередження на відносному ранжуванні в окремих групах. Стандарти виконання роботи встановлюються з використанням мінімальних рівнів компетентності відповідного застосованого тесту.

Обидві форми судження мають свої переваги при різних обставинах. Наприклад, посилання на темпоральну «норму» корисне при визначенні того, які кандидати з пулу повинні бути відібрані як найкращі. 3 іншого боку, при визначенні того, хто успішно завершить навчання, було б більш доречно застосовувати критерії, оскільки значна частка або всі кандидати з цієї групи можуть бути однаково кваліфікованими.

Традиційна форма оцінювання в медичній освіті - це оцінювання експертами-лікарями. Зазвичай, використовується експертне оцінювання, самооцінювання, а в разі інтернів - персональне чи колективне оцінювання викладацьким складом. На сьогодні до визначення якості навчання залучаються також особи, які не $\epsilon$ лікарями (методика «540 градусів»).

На завершення зупинимося на питаннях «коли» та «як часто» повинно проводитися оцінювання знань, умінь і компетентностей. Підкреслимо, що тестування може відбуватися в будь-який час протягом навчального курсу. Це може статися на початку курсу (попереднє тестування, що інколи називається базисним), під час або протягом усього курсу (моніторинг знань та умінь) або в кінці курсу (підсумкове тестування).

Базисне тестування корисне, оскільки, по-перше, вказує на можливість засвоєння курсу, а по-друге, дозволяє забезпечити певну індивідуалізацію навчання.

Моніторингове оцінювання - в тому сенсі, що звертає увагу на аспекти навчального курсу, які слухачами засвоєнні, дозволяє їм підвищити мотивацію до подальшого навчання, виправити викривлення в розумінні окремих аспектів в разі потреби.

Нарешті, остаточне оцінювання курсу - підсумкове тестування надає можливості оцінити ступінь досягнення загальних цілей навчальної програми. На відміну від попередніх процедур підсумкове оцінювання призначено для отримання інтегральної інформації про навчанні лікаря (під час безперервного професійного розвитку) з усіх можливих джерел і визначення того, чи були цілі курсу належним чином виконані. Ще однією відмінністю є наявність рекомендацій, що, зазвичай, з'являються в кінці курсу та використовуються для прийняття рішень про подальший розвиток спеціаліста. Метою $є$ конкретне визначення що було вивчено із заданою повнотою, які прогалини виявлено в навчанні та як побудувати індивідуальну освітню траєкторію.

Отже, матеріали, що отримуються під час тестування часто не мають характеристик надійності, 
стійкості, несуперечливості. Саме в цих випадках проявляється майстерність викладачів при оцінюванні якості підготовки спеціалістів. Можна не повторювати, що відповідальність викладачів має вирішальне значення як у подальшій долі спеціаліста, який навчається чи здійснює свій професійний розвиток, так і в забезпеченні здоров’я пацієнта, який довіряється лікарю. Відповідно, найбільші ризики визначаються в клінічній практиці, де об’єктивне оцінювання професіональної майстерності безпосередньо впливає на якість надання медичної допомоги. Надзвичайно великого значення набувають інтегральні оцінки.

Важливим міркуванням при розробленні інтегрального методу оцінювання знань і компетентностей є його класифікація та оцінювання його результатів. У цілому, користуються двома категоріями оцінок - формативною та сумативною.

Формуюче оцінювання — передбачає збір результатів із різних джерел оцінювання. Ці результати потім використовуються для побудови графіка прогресу суб’єкту навчання в рамках конкретного навчального курсу. Важливо відзначити, що формуюча оцінка використовує інформацію «зворотного зв’язку» в процесі навчання та викладання для забезпечення постійної конструктивної інформації про сильні та слабкі сторони суб'єкту навчання під час курсу. Цей зворотний зв’ язок персонально орієнтований на тих, хто навчається і не фокусується на їх рейтингу в рамках певної групи. В той же час подібне оцінювання може бути спрямовано й на підвищення якості програми, але не використовується для прийняття рішень про проходження або невдачі навчального курсу.

Сумативним (підсумковим) вважається оцінювання, що допомагає прийняти рішення про продовження або закриття програми, про розширення її сфери. Вважається, що сумативне оцінювання має здійснюватися з урахування даних прогнозної (попередньої) процедури (виконується перед початком реалізації програми навчання), а також проміжного оцінювання, що здійснюється під час реалізації навчання. При цьому метою проміжного оцінювання є оцінювання рівня досягнення запланованих цілей у світлі попереднього оцінювання, особливо враховуючи конкретні результати.

Для інтегральної оцінки засвоєння знань запропоновано багато методичних підходів. Наприклад, у популярній таксономії Блума використовується шість модулів: «Знання» - конкретного матеріалу, термінології, фактів, визначень, критеріїв тощо; «Розуміння» - пояснення, інтерпретація, екстраполяція; «Застосування» — використання методів, концепцій, принципів у нових ситуаціях; «Аналіз» - взаємозв'язків, принципів побудови; «Синтез» - розроблення плану та можливої системи дій, отримання системи абстрактних відносин; «Оцінювання» - судження на основі наявних даних, судження на основі зовнішніх критеріїв. Кількісна характеристика кожного з перелічених процесів, на жаль, досі неформалізована. Тому процедури цифровізації підходу потребують подальшої систематизації.

Оцінювання якості навчання лікарями. Цей метод $\epsilon$ найбільш широко використовуваним і прийнятим методом особливо при оцінюванні інтернів. Основою такого підходу є глибинне переконання в тому, що медичні експерти краще, ніж навіть досвідчені викладачі, вміють розрізняти тонкощі та складності своєї області. Це підтверджується даними, які показують, що глобальні рейтингові шкали (які вимагають від оцінювача розуміння предметної області контенту) є більш точними, ніж контрольні списки для оцінювання досвіду при адмініструванні експертом. Досить часто застосовуються методики «360 градусів», «540 градусів» та інші.

Самооцінювання. Воно теоретично привабливе, оскільки дозволяє суб'єктам навчання брати на себе відповідальність за свій власний освітній процес. У медичному співтоваристві безперервна освіта визначається оцінюванням лікарем своїх потреб у навчанні та вважається професійною вимогою. Проте, незважаючи на свою привабливість, результати досліджень самооцінювання в сфері вищої освіти були неоднозначними. Кілька досліджень, проведених у форматі метааналізу свідчать, що суб’ єкти навчання недостатньо добре оцінюють свою власну успішність, у той час, коли самооцінювання $є$ важливим інструментом інтегрального визначення ефективності навчання [200].

Оцінювання «виживання знань». Термін включає оцінювання ступеня збереження отриманого матеріалу з напряму. Зрозуміло, що цей період залежить не тільки від індивідуальних зусиль, але і від підготовки та мистецтва педагога. Актуальність 
вивчення якості знань протягом навчання в медичному університеті, при післядипломному медичному навчанні та безперервному професійному розвитку, що зберігаються в пам'яті протягом періоду навчання та можуть бути використані в подальшій професійній діяльності важко переоцінити. Більш того безперечним $є$ й розвиток довготривалої пам'яті, особливостями якої можуть стати практично необмежений час зберігання та розвитку знань, що можна розглядати як «набір організованих висловлювань фактів чи ідей, представляючи аргументоване судження або експериментальний результат, інформація про який передається через комунікаційне середовище в деякій систематичній формі». Важливим ефектом вивчення знань, що збереглися, $\epsilon$ виявлення елементів, які забезпечують їх системність, взаємозв'язок і можливість коректного доповнення новими відомостями. Саме тому структуризація знань, використання онтології знань, а також відповідний контроль упорядкування персональних знань може стати наступною стратегією оцінювання якості навчання. Порушення системності освіти робить практично неможливим ефективне використання нових знань, що нарощуються лавиноподібно.

Основи оцінювання компетентностей і знань при мобільному навчанні. Обгрунтовано значну кількість показників як самої організації процедури тестування, так і кількісного оцінювання компетентностей, знань і вмінь.

Розглядаючи характеристики організації та процедури комп'ютерної перевірки знань і компетентностей, зупинимося, перш за все, на обмеженнях часу як для окремого питання, групи питань так і всієї процедури. Часовий тиск часто утруднює іспит. 3 іншого боку, вирішення поставленого завдання може обумовити значні витрати часу особливо для напружених теоретичних і клінічних питань. Більшість намагань для скорочення часу далеко не завжди очевидні.

Незважаючи на докази, що форми оцінювання як, наприклад, вправи для міні-клінічного оцінювання покращують результати слухачів та все більшого визнання набувають практичні завдання. Слід підкреслити, що навчальна програма при мобільній освіті передбачає виявлення компетентностей (професіоналізм, етична поведінка, комунікативність тощо) досить у широкому діапазоні навиків.
Надаючи короткі оцінки безпосередньо тим, хто навчається на робочому місці, вимагаючи від них свідчень, коли вони демонструють компетентність і впевненість у цих сферах, вони мають змогу створити файл прогресу у співпраці зі своїми викладачами. Найчастіше це робиться при використанні індивідуального портфоліо.

Зауважимо також, що раніше навчальні установи добре оцінювали знання та компетентність з використанням традиційних методів оцінювання. Але менше зосереджувались на оцінюванні тих навиків і поведінки, якими спеціалісти повинні оволодіти, щоб ефективно та впевнено практикувати відповідно до професійних настанов. Останнє в певній мірі може ускладнити надання зворотного зв'язку.

Ключовими напрямами мобільної освіти (як i, взагалі освіти) має стати вироблення ефективної базової компетентності в галузі охорони здоров'я та медичної допомоги.

Стосовно оцінювання рівня етики та задоволеності, то традиційні цінності, установки й етичні уявлення під час впровадження нових технологій постійно ставляться під сумнів. Відповідно під сумнів змушені братися традиційні цінності та переконання про освіту. Тому впровадження мобільної освіти також пов'язано з новими етичними викликами, питаннями та проблемами.

Оцінювання задоволеності лікарів під час безперервного професійного розвитку у форматі мобільної освіти має постійно проводитися та висвітлюватися. Це один із ключів до вдосконалення процесу навчання. Ще одним важливим питанням може являтися оптимальне (за деяким критерієм) використання часу, що відводиться для навчання. У відповідь на надмірне використання технології висувається проста пропозиція - користувачі самі повинні ефективно регулювати та самостійно управляти своїм доступом до технологій. 3 іншого боку, таке розумне використання технологій пов'язано 3 медіаграмотністю, що обумовлена конвергенцією в Інтернеті всіх традиційних засобів комунікації.

Спрямованість має дати можливість покращення досвіду оцінювання лікарів шляхом створення системи, що дає швидкий зворотній зв'язок із ними.

Підвищення обгрунтованості процесу оцінювання особливо важливе та складне при характеристиці клінічних компетенцій і знань. Отримання 
валідної та інтегральної характеристики підготовленості лікаря під час безперервного професійного розвитку представляє непросту процедуру. Найбільше занепокоєнь викликає обгрунтованість бальних інтерпретацій дій суб’єктів навчання. Але одна з причин використання формату балів, що є загальним, i одна з перешкод для збирання додаткових доказів, - це час, необхідний для оброблення даних шкал, наприклад, шкали Лікерта. Подальше накопичення досвіду структурованих клінічних іспитів, використання мобільної технології отримання експертних оцінок, розпізнавання голосових зауважень, використання постійного зворотного зв’язку, безумовно, покращить якість рейтингової інформації.

Важливо підкреслити, що розроблення інфраструктури оцінювання дозволяє створювати, управляти та розгортати тести, анкети, навчальні матеріали в Інтернеті, мобільних телефонах і планшетах для використання лікарями як онлайн, так і офлайн. Зазвичай, дизайн системи комп'ютерного тестування включає: додатки для мобільних пристроїв і планшетів, що дозволять працювати в будьякий час та в будь-якому форматі з прийнятним дизайном і простотою використання, зручністю та продуктивністю; зворотний зв’язок для викладачів, що дозволяє швидко реагувати; інтегровані вебінструменти для швидкого та легкого оцінювання. Але основним є кластер оцінок, що знаходиться в центрі викладання та навчання. Дані, отримані в результаті типової процедури оцінювання, будуть інформувати викладача про те, наскільки добре лікар досяг результатів навчання в рамках конкретного навчального процесу. Оцінювання викладання, з одного боку, та оцінювання засвоєння, з другого боку, взаємно впливають один на одного. Отже, будь-яка характеристика навчального процесу може бути належним чином розроблена для надання корисної інформації тільки в тому випадку, якщо чітко усвідомлюється мета викладання та вивчення конкретного предмета.

Додаткові показники для оцінювання якості мобільної освіти. Враховуючи відносно невеликий час прямого спілкування викладачів і лікарів під час мобільного навчання рекомендується використовувати додатковий інструментарій якості підготовки спеціалістів. До них відносяться: керовані професійні дискусії між суб’єктами навчання та тьюторами; докази виконання завдань у письмовій або відео-формі; записи рольових ігор або презентацій; документальні експертні підтвердження робити суб’єктів навчання тощо. Докази цих дій потім збираються в індивідуальні портфоліо. Зауважимо, що наразі документальна діяльність підкреслюється постановкою цілей на виконання професійних ідеалів навчання протягом усього життя.

Поліпшення процедур спілкування між зацікавленими сторонами в процесі оцінювання якості навчання є незвичними в прямому контексті вищої освіти. Важливо підкреслити, що освітня діяльність наразі відбувається у багатьох місцях окрім медичного навчального закладу: в ряді різних клінічних і медичних закладів, амбулаторіях, при надані медичної допомоги на дому пацієнта тощо. При цьому персонал на перелічених майданчиках може по-різному ставитися як до лікаря, так і до самого навчального нагляду. Відсутність узгодженого та спільного розуміння якості навчання - досить заплутаний процес, що ускладнює взаємодію з експертами. Тому для коректного вирішення питань якості навчання, досконалості підвищення кваліфікації лікарів, як правило, потрібно відійти від стандартних уявлень про класичні підходи університетського навчання. Це в майбутньому обумовить появу принципово нового оцінювання. Перш за все, це стосується залучення до процедур оцінювання неакадемічного медичного персоналу. Враховуючи, таким чином, бажання вбудувати оцінювання у практичні умови підготовки, слід розглянути найбільш ефективний спосіб надання можливості лікарям під час БПР відповідати на оцінювання в складних умовах, таких як лікарня.

Останні дослідження показали неоднорідність засвоєння навчальних розділів. Так, з усіх модальностей навчання, таких як оцінювання здоров'я, нетрадиційні методі діагностування, гомеопатія найменш відомі як серед студентів, так і лікарів. Крім того, суб’єкти навчання за мобільними технологіями більше не впевнені, що очікування пацієнта, його переконання про здоров’я та духовні цінності повинні бути включені в процес догляду за пацієнтом. Тому окрім спеціалізованих показників досить часто використовуються так звані ненаправлені характеристики.

Будь-який механізм оцінювання повинен бути підзвітний усім «зацікавленим сторонам», що 
беруть участь у його роботі. Це хоч і не головний принцип, але з нього мають «випливати» інші характеристики надійного інструменту оцінювання. До класичної охорони здоров'я та практичної медицини зацікавлені сторони включають лікарів, інтернів, студентів, клінічних викладачів, ліцензуючи органи та в кінцевому рахунку співтовариство, що буде обслуговувати лікар. Для полегшення підзвітності оцінювання повинно бути обгрунтованим і здатним забезпечити логічний аналіз або пояснення результатів.

Клінічна медицина практикується в різноманітних і часом непередбачуваних умовах. Тому обраний метод оцінювання повинен бути гнучким і дозволяти експерту оцінювати повний клінічний спектр аналізованої предметної області багаторазово та в різних умовах (наприклад, при проведенні планових та екстрених оперативних втручань).

Щоб бути ефективним у цілому, необхідно оцінювати всі відповідні цілі та документувати результати іспиту для курсу, що був розроблений для оцінювання. Структура компетентностей, що визначає основні компетенції лікаря (медичний експерт, професіонал, комунікатор, співробітник, менеджер, захисник здоров'я та вчений), віддзеркалює надійність клінічної практики. 3 цієї точки зору на практиці клінічний педагог може краще зрозуміти важливість комплексних механізмів оцінювання лікарів.

Для полегшення прийняття оцінювання всіма зацікавленими сторонами вона повинна бути портативною, економічно ефективною, практичною й обмежувати фізичні та людські потреби. Це важливо, оскільки оцінювання того, що податки обмежують ресурси, навряд чи знайде широке визнання. Однак при деяких обставинах ці міркування можуть бути пом'якшені. Наприклад, при ліцензуванні чи інших експертизах із збільшеною відповідальністю може використовуватися більш трудомістке та дороге оцінювання якщо доведено, що воно перевершує інші доступні тести. Такі обстеження, як об'єктивне структуроване клінічне обстеження чи об'єктивне структуроване оцінювання технічних навиків (обговорювані нижче), $€$ прикладами ресурсомістких, але цінних інструментів оцінювання.

Для максимізації своєї функції оцінювання повинно проводитися якомога ближче до цільової поведінки. Невиправдана затримка призводить до погіршення відкликання цільових подій і тим самим підвищує суб'єктивність оцінювання. Крім того, результати оцінювання повинні бути негайно доведені до відома екзаменованих (та інших відповідних сторін). Невиконання цієї вимоги позбавляє зацікавлені сторони повної корисності оцінювання (наприклад, функції зворотного зв' язку або планування навчальних програм).

Щоб бути ефективною, важливість оцінювання повинно бути очевидним для всіх залучених зацікавлених сторін. Результати оцінювання, сприятливі чи ні, повинні використовуватися для полегшення навчання та впливати на просування і рішення по плануванню навчальних програм. Оцінювання, що розглядається як несуттєве, не може виконувати ці функції, оскільки її результати представляються непридатними для використання.

Нами, як і в близьких за філософією системах [15], запропоновано користуватися багатопараметричними системи моніторингу, що складаються з двох пристроїв: один із них розміщується у терапевта (master device), а другий - у пацієнта (service device), працюють синхронно, щоб допомогти з реабілітаційними заходами. Але останні $\epsilon$ перспективним інструментом у реалізації процесів безперервного професійного розвитку.

Розглянемо ще один інструмент, що дає можливість формувати компетентність реабілітологів. Він отримав сьогодні широке розповсюдження як у теоретичних узагальненнях, так і завданнях мобільної медицини. Мова про застосування логіки ієрархізації клінічних даних — онтологічних моделях. У нашому дослідженні застосовано неканонічну концептуальну онтологію. Вибір саме такого типу онтології обумовлений багато направленістю патологій пацієнтів при дистанційному моніторингу. В цьому випадку кожна база знань звертається до певної предметної області та визначає канонічний спосіб представлення будь-якого факту про неї. У глобальній онтології вираження концептів і правила представлені в базових концептах предметної області, що визначають широкий спектр термінів, корисних для користувачів при формулюванні запиту до даних.

Практичні результати оцінювання знань лікарів санаторно-курортного профілю. Оцінювання знань лікарів санаторно-курортного профілю 
проводилося під час циклів тематичного вдосконалення кафедри медичної інформатики НУОЗ України імені П. Л. Шупика протягом 2018-2020 років у санаторії «Квітка полонини». За цей період пройшли навчання та перевірку знань 65 лікарів санаторіїв Закарпаття. Оцінювання знань проводилося за допомогою програмного забезпечення, розробленого та сертифікованого в НУОЗ України імені П. Л. Шупика. Після отримання офіційних результатів тестування останні оброблялися з метою отримання оцінок валідності, релевантності, додаткових оцінок (управління компетентностями, спрямованості навчання тощо). Дані наведено в табл. 2.

Таблиця 2

Оцінювання знань лікарів санаторно-курортного профілю

\begin{tabular}{|c|c|c|c|c|c|c|c|c|c|c|c|c|}
\hline \multirow{2}{*}{ Показники } & \multirow{2}{*}{$\begin{array}{c}\text { Кіль- } \\
\text { кість } \\
\text { спо- } \\
\text { стере- } \\
\text { жень }\end{array}$} & \multicolumn{3}{|c|}{2018 рік } & \multicolumn{3}{|c|}{2019 рік } & \multicolumn{3}{|c|}{2020 рік } & \multirow{2}{*}{$\begin{array}{c}\text { Вірогід- } \\
\text { ність } \\
\text { тенден- } \\
\text { ції, Р }\end{array}$} & \multirow{2}{*}{$\begin{array}{c}\text { Матема- } \\
\text { тичне } \\
\text { споді- } \\
\text { вання }\end{array}$} \\
\hline & & $\mathrm{N}$ & абс. & $\%$ & $\mathrm{~N}$ & абс. & $\%$ & $\mathrm{~N}$ & абс. & $\%$ & & \\
\hline $\begin{array}{l}\text { Кількість осіб, які } \\
\text { склали іспит }\end{array}$ & 65 & 18 & 14 & 77,8 & 25 & 21 & 84,0 & 22 & 4 & 19,9 & $>0,05$ & 82,7 \\
\hline $\begin{array}{l}\text { Кількість осіб, які } \\
\text { не склали іспит із } \\
\text { першого разу }\end{array}$ & 65 & 18 & 4 & 22,2 & 18 & 4 & 16,0 & 18 & 3 & 13,6 & $>0,05$ & 17,3 \\
\hline $\begin{array}{l}\text { Валідність } \\
\text { процедури }\end{array}$ & 63 & \multicolumn{3}{|c|}{0,8} & \multicolumn{3}{|c|}{0,9} & \multicolumn{3}{|c|}{0,9} & $<0,05$ & 0,9 \\
\hline $\begin{array}{l}\text { Релевантність } \\
\text { процедури }\end{array}$ & 62 & \multicolumn{3}{|c|}{0,7} & \multicolumn{3}{|c|}{0,8} & \multicolumn{3}{|c|}{0,8} & $<0,05$ & 0,7 \\
\hline $\begin{array}{l}\text { Пертинентність } \\
\text { процедури }\end{array}$ & 62 & \multicolumn{3}{|c|}{0,7} & \multicolumn{3}{|c|}{0,7} & \multicolumn{3}{|c|}{0,7} & $<0,05$ & 0,7 \\
\hline $\begin{array}{l}\text { Надійність } \\
\text { отриманих оцінок }\end{array}$ & 62 & \multicolumn{3}{|c|}{0,8} & \multicolumn{3}{|c|}{0,8} & \multicolumn{3}{|c|}{0,9} & $<0,05$ & 0,8 \\
\hline $\begin{array}{l}\text { Оцінювання } \\
\text { компетентності } \\
\text { (за Міллером) }\end{array}$ & 60 & \multicolumn{3}{|c|}{0,8} & \multicolumn{3}{|c|}{0,9} & \multicolumn{3}{|c|}{0,9} & $>0,05$ & 0,9 \\
\hline
\end{tabular}

Дані табл. 2. свідчать, що впровадження сучасних інформаційних технологій у стратегію трансферу знань не погіршує якість безперервного професійного розвитку лікарів-реабілітологів. Кількість осіб, які складають іспит залишається в діапазоні 80-90 відсотків. Більш того, відмічається щорічна тенденція до покращання знань і компетенцій. Хоч вірогідність тенденції ще не має відповідного рівня ( $\mathrm{p}=0,07)$, але сталість тренду дає можливість сподіватися на суттєве підвищення якості БПР при використанні інформаційних технологій. У той же час насторожують відносно невисокі значення валідності, особливо релевантності та пертинентності процедури оцінювання. Це обумовлює проведення спеціальних досліджень, що стосується бази знань, закладеної в систему оцінювання знань у даному випадку лікарів-реабілітологів. Наступна таблиця узагальнює дані про оцінювання знань лікарів у санаторіях при використанні мобільної медицини (табл. 3). 
Оцінювання компетентностей і знань при мобільній освіті

\begin{tabular}{|c|c|c|c|c|c|c|c|c|c|c|c|c|}
\hline \multirow{2}{*}{ Показники } & \multirow{2}{*}{$\begin{array}{c}\text { Кіль- } \\
\text { кість } \\
\text { спо- } \\
\text { стере- } \\
\text { жень }\end{array}$} & \multicolumn{3}{|c|}{2018 рік } & \multicolumn{3}{|c|}{2019 рік } & \multicolumn{3}{|c|}{2020 рік } & \multirow{2}{*}{\begin{tabular}{|c} 
Вірогід- \\
ність \\
тенден- \\
ції, Р
\end{tabular}} & \multirow{2}{*}{$\begin{array}{c}\text { Матема- } \\
\text { тичне } \\
\text { споді- } \\
\text { вання }\end{array}$} \\
\hline & & $\mathrm{N}$ & абс. & $\%$ & $\mathrm{~N}$ & абс. & $\%$ & $\mathrm{~N}$ & абс. & $\%$ & & \\
\hline $\begin{array}{l}\text { Кількість осіб, які } \\
\text { склали іспит }\end{array}$ & 52 & 15 & 11 & 73,3 & 14 & 12 & 85,7 & 23 & 19 & 82,6 & $>0,05$ & 80,8 \\
\hline $\begin{array}{l}\text { Кількість осіб, які } \\
\text { не склали іспит із } \\
\text { першого разу }\end{array}$ & 52 & 15 & 4 & 16,7 & 14 & 2 & 14,3 & 23 & 4 & 17,4 & $>0,05$ & 19,2 \\
\hline $\begin{array}{l}\text { Валідність } \\
\text { процедури }\end{array}$ & 52 & & 0,8 & & & 0,8 & & & 0,8 & & $<0,05$ & 0,8 \\
\hline $\begin{array}{l}\text { Релевантність } \\
\text { процедури }\end{array}$ & 50 & & 0,7 & & & 0,7 & & & 0,7 & & $<0,05$ & 0,7 \\
\hline $\begin{array}{l}\text { Пертинентність } \\
\text { процедури }\end{array}$ & 49 & & 0,6 & & & 0,7 & & & 0,7 & & $<0,05$ & 0,7 \\
\hline $\begin{array}{l}\text { Надійність } \\
\text { отриманих оцінок }\end{array}$ & 49 & & 0,8 & & & 0,8 & & & 0,8 & & $<0,05$ & 0,8 \\
\hline $\begin{array}{l}\text { Оцінювання } \\
\text { компетентності } \\
\text { (за Міллером) }\end{array}$ & 49 & & 0,8 & & & 0,9 & & & 0,9 & & $>0,05$ & 0,8 \\
\hline $\begin{array}{l}\text { Знання направлених } \\
\text { показників мобіль- } \\
\text { ної медицини, } \\
\text { \% від максимуму }\end{array}$ & 52 & & 18,7 & & & 25,8 & & & 21,8 & & $<0,05$ & 0,8 \\
\hline
\end{tabular}

3 табл. 3 бачимо, що показники якості підготовки при мобільній освіті незначно знизилися з 82,7 $\pm 5,3$ \% до 80,8 $\pm 5,4 \%$ (p>0,05). Також зменшились значення валідності, пертинентності та релевантності. Оцінюючи в цілому показники комп'ютерного контроля та компетентності можна зробити висновок про зменшення інтегральної вірогідності якості трансферу знань при мобільній освіті (р>0,05). Цікаво відзначити, що показники компетентності при цьому практично не змінилися. Це підкреслює той факт, що наявність постійної практичної діяльності під час мобільної освіти при відповідній консультативній підтримці допомагає зменшити фактори ризику стосовно сприйняття нових знань.
Висновки. 1. Запропоновано для завдань навчання лікарів санаторно-курортного спрямування користуватися логікою побудови ієрархії клінічних даних - онтологічних моделей. У глобальній онтології представлення концептів і правила, виражені в базових концептах предметної області, визначають широкий спектр термінів, корисних для користувачів при формулюванні запиту до даних.

2. Запропонована реабілітаційно орієнтована онтологія, що надає необхідні пояснення та забезпечує можливості персоналізації, засновані на структурних зв'язках між клінічними поняттями в онтології. Віддалене надання медичної допомоги можливе за умови відповідної концептуалізації, що базується на принципах обгрунтування сталих 
станів, тригерно-каскадних уявленнях, використання онтологій знань.

3. Педагогічний процес післядипломної освіти лікарів направлений на виховання конкурентоспроможного спеціаліста неможливий без залучення інноваційних технологій дистанційної освіти, що наближає лікаря до швидкого отримання нової професійної інформації.

4. На післядипломному етапі освіти лікаря-спеціаліста дистанційне навчання повинно стати важливою частиною навчального процесу. Спілкування з пацієнтами, й особливо людьми з інвалідністю, накладає особливі вимоги на реабілітологів відносно їхньої професійної підготовки в питаннях дотримання правил етики та деонтології. Удосконалення

\section{Література.}

1. Фактори ризику дистанційного навчання та механізми їх запобігання. Прийняття рішень під час технологічного процесу / Мінцер О. П., Ганинець П. П., Сарканич О. В. // Системи підтримки прийняття рішень. Теорія і практика: матер. наук.-практ. конф., м. Київ, 2017. - С. 105-106.

2. Мобільне навчання лікарів і провізорів: оцінювання знань: Метод. рекомендації / Мінцер О. П., Мохначов С. І., Мироненко Н. В., Сарканич О. В. - К.: НВП «Інтерсервіс», 2020. - 35 с.

3. Ключові тренди розвитку технологій передавання знань у системах післядипломної медичної освіти та безперервного професійного розвитку лікарів / Мінцер О. П., Суханова О. О., Сарканич О. В. та ін. // Медична інформатика та інженерія. - 2018. № 4. - С. 50-56.

4. Дистанційне управління процесами реабілітації пацієнтів / Мінцер О. П., Шевцова О. М., Сарканич О. В. // Медична інформатика та інженерія. - 2019. № 4. - С. 73-75.

5. Основи знань інтелектуальних систем / Гаврилова Т. А., Хорошевський В. Ф. - СПб.: Пітер; 2001. 384 c.

6. Модель покращення доступності та якості медичної допомоги сільському населенню з застосуванням телемедичних технологій : метод. рекомендації / Мінцер О. П., Матюха Л. Ф., Бабінцева Л. Ю. та ін. - К.; Івано-Франківськ : Вид-во Прикарпатського національного університету імені Василя Стефаника, 2012. - 26 c.

7. Cercone K. Characteristics of adult learners with implications for online learning design / Cercone K. // AACE J. - 2008. - № 16 (2). - P. 137-159.

8. European Region of the World Congress of Physical Therapy. Information paper with recommendations on continuing professional development // Brussels: знань морально-етичних і деонтологічних основ спілкування з пацієнтами та особливостями психологічного стану людей з інвалідністю сприятимуть безконфліктній атмосфері процесів лікування і відновлення здоров’я пацієнтів.

5. Загальне поширення інформації не гарантує iï якості та достовірності, хоча і сприяє формуванню більш свідомих і самостійних спеціалістів. Традиційна комунікаційна модель освіти поступилася місцем більш відкритим і партисипативним моделям, у рамках яких лікарі, діючи в широкому діапазоні навчальних середовищ і мереж, обмінюються інформацією та знаннями з іншими учасниками, що дозволяє здійснювати всеосяжне співробітництво та колективну побудову баз знань.

European Region of the World Congress of Physical Therapy, 2010. - Режим доступу: www.physio-europe. org.

9. Effectiveness of training in evidence-based medicine skills for healthcare professionals: a systematic review / Hecht L., Buhse S., Meyer G. // BMC Med Educ. -2016.№ 16 (1). - P. 103.

10. Cardiovascular and diabetes focused remote patient monitoring //VI Latin American congress on biomedical engineering CLAIB 2014, Parana, Argentina; 2014 Oct 29-31. - Springer International Publishing, Cham, 2015.P. 568-571.

11. Remote patient monitoring: a comprehensive study / Malasinghe L. P., Ramzan N., Dahal K. // J Ambient Intel Human Comput. - 2019. - № 10. - P. 57-76.

12. Systematic Review of Healthcare Applications for Smartphones / Mosa A. S. M., Yoo I., Sheets L. A. // BMC Medical Informatics and Decision Making. 2012. - № 12 (1). - P. 67.

13. Do physiotherapists attitudes towards evidence based practice change as a result of an evidence based educational program / Stevenson K., Lewis M., Hay E. // J Eval Clin Pract. - 2004. - № 10. - P. 207-217.

14. The assessment of professional competence: building blocks for theory development / van der Vleuten C. P. M., Schuwirth L. W. T., Scheele F. et al. // Best Practice \& Research Clinical Obstetrics \& Gynecology. - 2010. - № 24 (6). - P. 703-719.

15. Warfield J. N. Developing interconnection matrices in structural modeling / Warfield J. N. // IEEE Trans. Syst. Man Cybern. - 1974. - № 1. - P. 81-87.

16. Construction of a new questionnaire for assessing physical therapy student attitudes towards their education and profession and testing its validity and reliability / Tedla J. S. // Physical Therapy Rehabilitation Science. 2017. - № 6 (1). - P. 20-25. 
17. WHO. Template for Rehabilitation Information Collection (TRIC): a tool accompanying the Systematic Assessment of Rehabilitation Situation (STARS). ISBN 978-92-4-151601-3.

18. Ensuring the continuity of medical care at the stage of patients' rehabilitation / Sarkanich O., Shevtsova O., Mintser O. // Wiadomosci lekarskie. - Tom LXXII. 2019. - № 2. - P. 275-278.

\section{References.}

1. Mintser, O.P., Haninets, P.P, Sarkanych, O.V., Nikitiuk, D.V. (2017). Faktory ryzyku dystantsiinoho navchannia ta mekhanizmy yikh zapobihannia. Pryiniattia rishen pid chas tekhnolohichnoho protsesu. Systemy pidtrymky pryiniattia rishen. Teoriia i praktyka. [Risk factors for distance learning and mechanisms for their prevention. Decision making during the technological process. Decision support systems. Theory and practice]. (Materialy nauk.-prakt. konf.),(Kyiv,2017), 105-106. [In Ukrainian].

2. Mintser, O.P., Mokhnachov, S.I., Myronenko, N.V., Sarkanych, O.V. (2020). Mobilne navchannia likariv i provizoriv: otsiniuvannia znan (metodychni rekomendatsii) [Mobile training of doctors and pharmacists: assessment of knowledge (guidelines)] Natsionalna medychna akademiia pisliadyplomnoi osvity imeni P.L. Shupyka MOZ Ukrainy (National Medical Academy of Postgraduate Education named after PL Shupyk of the Ministry of Health of Ukraine). Kyiv: TOV NVP Interservis. [In Ukrainian].

3. Mintser, O.,P., Sukhanova, O.O., Sarkanych, O.V. ta in. (2018). Kliuchovi trendy rozvytku tekhnolohii peredavannia znan u systemakh pisliadyplomnoi medychnoi osvity ta bezperervnoho profesiinoho rozvytku likariv [Key trends in the development of knowledge transfer technologies in postgraduate medical education and continuing professional development of physicians]. Medychna informatyka ta inzheneriia (Medical informatics and engineering), 4(44), 50-56. [In Ukrainian].

4. Mintser, O.P., Shevtsova, O.M., Sarkanych, O.V. (2019). Dystantsiine upravlinnia protsesamy reabilitatsii patsiientiv. [Remote control of patient rehabilitation processes]. Medychna informatyka ta inzheneriia (Medical informatics and engineering), 4, 73-75. [In Ukrainian].

5. Havrylova, T.A., Khoroshevskyi, V.F. (2001). Osnovy znan intelektualnykh system [Fundamentals of knowledge of intelligent systems]. SPb.: Piter. [In Ukrainian].

6. Mintser, O.P. , Matiukha, L.F., Babintseva, L.Yu. ta inshi. (2012). Model pokrashchennia dostupnosti ta yakosti medychnoi dopomohy silskomu naselenniu z zastosuvanniam telemedychnykh tekhnolohii : metod. Rekomendatsii [Model of improving the availability and quality of medical care for the rural population using telemedicine technologies: a method. recommendations]. K.; Ivano-Frankivsk : Vyd-vo Prykarpatskoho natsionalnoho universytetu imeni Vasylia Stefanyka. [In Ukrainian].

7. Cercone, K. (2008). Characteristics of adult learners with implications for online learning design. AACE J., 16(2), 137-159.

8. European Region of the World Congress of Physical Therapy. Information paper with recommendations on continuing professional development. Brussels: European Region of the World Congress of Physical Therapy; 2010. Available from: www.physio-europe.org.

9. Hecht, L., Buhse, S., Meyer, G. (2016). Effectiveness of training in evidence-based medicine skills for healthcare professionals: a systematic review. BMC Med Educ., 16 (1), 103.

10. Cardiovascular and diabetes focused remote patient monitoring. (2014). VI Latin American congress on biomedical engineering CLAIB 2014, Parana, Argentina; Oct 29-31. Springer International Publishing, Cham, 2015. 568-71.

11. Malasinghe, L.P., Ramzan, N., Dahal, K. (2019). Remote patient monitoring: a comprehensive study. J Ambient Intel Human Comput., 10, 57-76.

12. Mosa, A.S.M., Yoo, I, Sheets, L. (2012). A Systematic Review of Healthcare Applications for Smartphones. BMC Medical Informatics and Decision Making, $12(1), 67$.

13. Stevenson, K., Lewis, M., Hay, E. (2004). Do physiotherapists attitudes towards evidence based practice change as a result of an evidence based educational program. J Eval Clin Pract., 10, 207-17.

14. Van der Vleuten, C.P.M., Schuwirth, L.W.T., Scheele, F., Driessen, E.W., Hodges, B. (2010). The assessment of professional competence: building blocks for theory development. Publication: Best Practice \& Research Clinical Obstetrics \& Gynecology. Publisher: Elsevier, 24(6), 703-19.

15. Warfield, J.N. (1974). Developing interconnection matrices in structural modeling. IEEE Trans. Syst. Man Cybern., 1, 81-87.

16. Tedla, J.S. (2017). Construction of a new questionnaire for assessing physical therapy student attitudes towards their education and profession and testing its validity and reliability. Physical Therapy Rehabilitation Science, 6(1), 20-25.

17. WHO. Template for Rehabilitation Information Collection (TRIC): a tool accompanying the Systematic Assessment of Rehabilitation Situation (STARS). ISBN 978-92-4-151601-3.

18. Sarkanich, O., Shevtsova, O., Mintser, O. (2019). Ensuring the continuity of medical care at the stage of patients rehabilitation. Wiadomosci lekarskie, LXXII, 2, 275-278. 